\title{
Habitat Variation and its Effect on the Morphological Characters of Three Wild Plant Species in El-Riyadh City
}

\author{
W.K. Taia ${ }^{*}$ and H.A. El-Olyan ${ }^{2}$ \\ ${ }^{1}$ Alexandria University, Faculty Science, Botany Department, \\ Alexandria, Egypt, ${ }^{2}$ Girl`s College of Education, \\ El-Riyadh, Kingdom of Saudi Arabia

$$
\text { تغير البيئات وتأثيرها على صفات الشكل الخارجي لثلاث أنواع نباتية منتشرة في مدينة الرياض هيفاء العليان }
$$

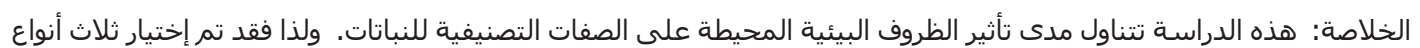

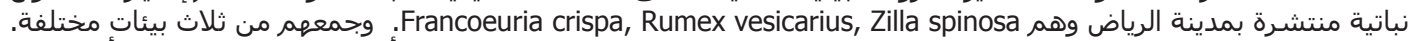

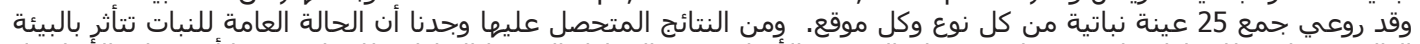

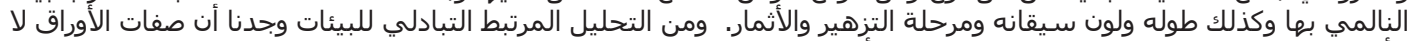
تتأثر يصورة معنوية تبعا للتغير في البيئات. ولذا فأننا نوصي بالإعتماد عليها في التصنيف وعمل العلاقات بين النبات النباتات.

ABSTRACT: Fourteen taxonomic characters have been studied in three wild plant species in El-Riyadh city; Francoeuria crispa, Zilla spinosa and Rumex vesicarius; collected from three different habitats. The results of this study revealed that the habitats have insignificant effect on the leaf characters in spite of the slight effect on the general status, fruiting stage and color of the plants. Cross correspondence analysis between the habitats revealed that the variations were within the confidence limits. It is concluded that leaf characters can be used as an effective selection criterion for classification.

Keywords:

\section{Introduction}

Morphological changes in response to environmental disorders are known as phenotypic plasticity, whereas internal changes are considered adaptation. Taxonomists have to be accurate in deciding whether the studied characters are according to environment or specified to that plant. Radford (1986) stated that evidence from plant morphology provided the basic language for plant characterization, identification, classification and relationships. Thus, vegetative, morphological characters, especially that of the leaf, have been employed as a basis for classification since the early days of taxonomy. In fact, vegetative characters can be unreliable because of the similarity between unrelated species, but even so Davis and Heywood (1973) deplored the neglect of morphological characters as one of the most serious errors which delay the achievement of a natural system. Schlichting and Levin (1984), Schlichting (1986), Sultan (1987), Pianka (1988) and Grime (1994) have indicated the response of plants to environmental changes which may be under genetic control or may evolve under selection. In the last case, new traits evolved which allowed species to adjust to new environments (Mazer and Gorchov, 1996). Dunn and Sharitz (1991) and Mazer and Wolfe (1992) have found differences in plant biomass, shoot length and even reproductive growth in Murdannia keisak grown in different populations. Taxonomists need to be precise in choosing the characters they rely on it.

This work deals mainly, with the study of fourteen phenotypic characters in three wild species; Francoeuria crispa, Zilla spinosa and Rumex vesicarius. These species are widely distributed in

\footnotetext{
$\overline{* \text { Corresponding author }}$
} 
El-Riyadh City, Saudi Arabia. The aim of this work was to investigate the most stable characters which can be of use in taxonomy. Meanwhile, we have to know the limits of morphological alteration according to environmental changes.

\section{Materials and Methods}

The materials were collected from three different habitats in El-Riyadh city; 1 - El-Nargis district, north El-Riyadh, in which the soil is dry, hard, with high salt contents and covered with rocks, 2 - The beginning of El-Riyadh El- Kharj road, south east El-Riyadh, in which the soil is calcareous, loamy and affected by the nearby factories and 3 - Wadi Hanifa, south El-Riyadh, in which the soil is sandy with a high water content. These habitats are completely different in their soil characteristics (Taia and El-Ghanem, 2001). At least 20 specimens from each species per location were used. All the specimens were collected during the middle of February 2002. The first three characters were measured in the field, while the rest were studied in the laboratory at El-Riyadh. For plant moisture contents 100 grams of the shoot system was dried at $95^{\circ} \mathrm{C}$ overnight. The data obtained from each species/location were summarized using a CHANDAT computer programme. Then a cross correspondence analysis for the summarized data was carried out to evaluate the effect of the habitats on the studied characters.

\section{Results}

Table 1 summarizes the studied characters and their status in the different species gathered from the three habitats. F. crispa in the first location (El-Nargis district) is more widely distributed than in the other two locations. But, in spite of its abundance it was dry, short, the colour of the plant was whitish green and it was sparsely branched. In the second location (El-Riyadh- El-Kharj road) the density of the plant was low but it was flourishing and was taller, although it

Table 1. Characters studied and their status in three habitats.

\begin{tabular}{|c|c|c|c|c|c|c|c|c|c|}
\hline \multirow[b]{3}{*}{ Sp. Char. } & \multicolumn{9}{|c|}{ Location/Habitat } \\
\hline & \multicolumn{3}{|c|}{ El-Nargis district } & \multicolumn{3}{|c|}{ El-Riyadh- El-Kharj } & \multicolumn{3}{|c|}{ Wadi Hanifa } \\
\hline & F.crispa & Z.spin. & R.vesí. & F.crispa & Z.spni. & R.vesí. & F.crispa & Z.spin. & R.vesí. \\
\hline Density & 3 & 3 & 3 & 1 & 1 & 2 & 2 & 2 & 1 \\
\hline Appearance & 1 & 2 & 3 & 1 & 2 & 2 & 3 & 3 & 1 \\
\hline Sh.Syst.L. & $20-30$ & $70-85$ & $10-22$ & $40-62$ & $65-72$ & $10-15$ & $80-110$ & $95-150$ & $6-10$ \\
\hline Color & 1 & 2 & 2 & 1 & 2 & 2 & 3 & 4 & 4 \\
\hline Branches & 2 & 2 & 2 & 2 & 3 & 2 & 4 & 4 & 1 \\
\hline Leaf color & 3 & 1 & 3 & 3 & 1 & 3 & 3 & 4 & 2 \\
\hline Leaf marg. & 2 & 1 & 1 & 3 & 1 & 1 & 2 & 1 & 1 \\
\hline Leaf apex & 1 & 1 & 1 & 1 & 1 & 1 & 1 & 1 & 2 \\
\hline \multirow[t]{2}{*}{ Leaf length } & $1.7-2.2$ & $1.1-1.5$ & $4.5-5.2$ & $2.2-2.5$ & $1.6-2.3$ & $3.0-4.0$ & $2.0-2.2$ & $1.5-1.8$ & $2.5-4.0$ \\
\hline & 2.05 & 1.4 & 4.97 & 2.38 & 2.05 & 3.2 & 2.14 & 1.61 & 3.2 \\
\hline \multirow[t]{2}{*}{ Leaf width } & $0.3-0.4$ & $0.2-0.3$ & $2.5-2.9$ & $0.3-0.5$ & $0.3-1.0$ & $2.0-3.5$ & $0.4-0.5$ & $0.4-0.5$ & $2.0-3.2$ \\
\hline & 0.38 & 0.27 & 2.75 & 0.42 & 0.6 & 2.8 & 0.45 & 0.41 & 2.8 \\
\hline Leaf shape & 1 & 1 & 3 & 1 & 2 & 4 & 1 & 1 & 4 \\
\hline Moisture & 62.5 & 60.6 & 85.62 & 73.1 & 76.8 & 88.62 & 69.5 & 69.6 & 87.18 \\
\hline Fruit & 0 & 2 & 2 & 0 & 1 & 1 & 0 & 1 & 0 \\
\hline Fruit shape & 0 & 2 & 1 & 0 & 2 & 1 & 0 & 2 & 0 \\
\hline
\end{tabular}

Characters: Density 1 = low, 2 = moderate, $3=$ dense; Appearance $1=$ dry, $2=$ slightly flourished, $3=$ flourished; Shoot system length in $\mathrm{cm}$; Colour of the shoot system $1=$ whitish green, $2=$ green, $3=$ bright green $4=$ olive green; Density of branches 1 = unbranched, 2 = branched, 3 = densely branched, 4 = very densely branched; Leaf colour $1=$ pale green, $2=$ green, $3=$ olive green, $4=$ dark green; Leaf margin $1=$ entire, $2=$ undulated, $3=$ sinuated; Leaf apex 1 = acute, 2 = rounded; Leaf length in $\mathrm{cm}$; Leaf width in $\mathrm{cm}$; Leaf shape $1=$ lanceolate, 2 = ovate-lanceolate, 3 = obovate, $4=$ broadly-obovate; Plant moisture content (percentage); Fruit $0=$ absent, $1=$ present, 3 =dense; Fruit shape $0=$ absent, $1=$ flat, $2=$ globular. Figures in parenthesis are mean values. 


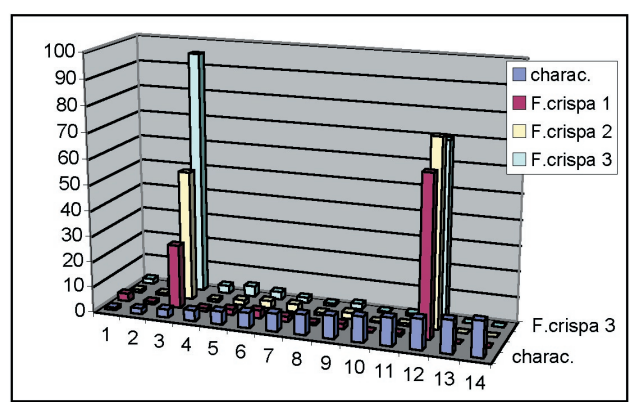

Figure 1. Variation in F. crispa growing in the three habitats.

was still whitish green and the branches were few. In Wadi Hanifa F. crispa was moderately abundant and the plants were flourishing, being tall, bright green and with many branches. In the three habitats there were neither fruits nor flowers.

Zilla spinosa is widely distributed in the first location, and its status was very good. It was flourishing, being tall and green in color but the branches were few. The distribution of Z. spinosa in the second location was sparse, but even so its status was very good as in the first location. This species was moderately abundant in Wadi Hanifa and indicated its good status with many branches. The plants were in the fruiting stage in the three locations, but the density of the fruits was higher in the first location.

The data obtained for $R$. vesicarius were completely different from that of the previous two species. Its presence in Wadi Hanifa was less than in the other two habitats. At the same time, plants found

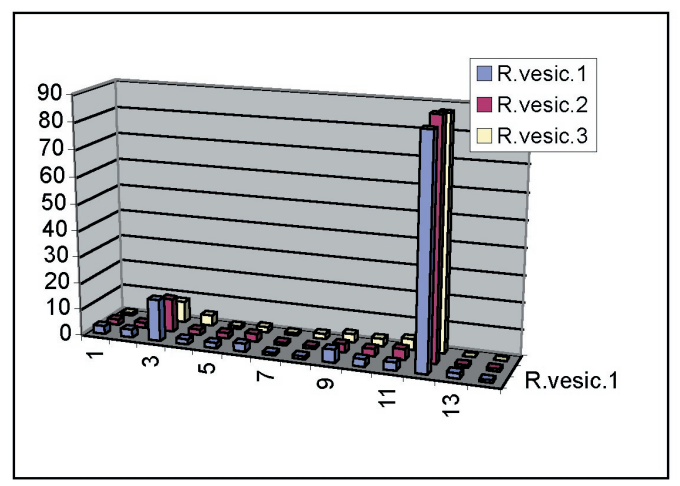

Figure 3. Variation in $R$. vesicarius growing in the three habitats.

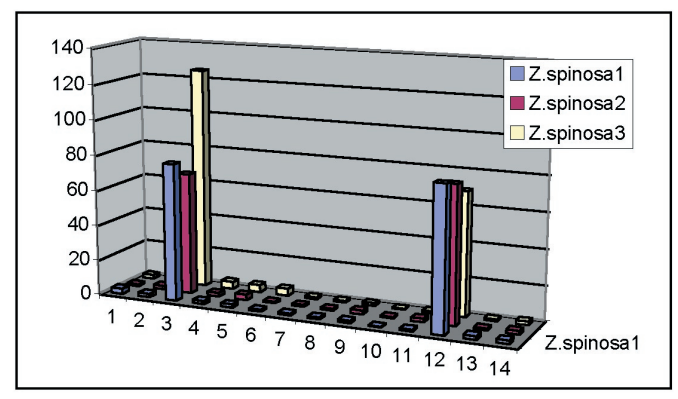

Figure 2. Variation in Z. spinosa growing in the three habitats.

in Wadi Hanifa were dry, short, olive green, not branched and without any fruits, whereas in the first two locations it was dense and flourishing, slightly taller, green in color, with few branches and in the fruiting stage.

Leaf characters for the three species were more fixed, whereas the moisture contents of the plants differed slightly according to the location. These results are demonstrated in Figures 1, 2, and 3. The cross correspondence analysis between each pair of habitats shows that the differences between the habitats were within the confidence limits. Accordingly the effect of the habitats on the studied characters were insignificant.

\section{Discussion}

The effect of habitat type on vegetation has recently been discussed (El-Demerdash et al.,1995; Taia and El-Ghanem, 2001). But how much the variations in the soil characters and the surrounding environment affect the phenotypic characters of the same species has gained less attention. Schlichting and Levin (1984) have noticed the effect of environmental conditions on the morphology of annual Phlox. Dunn and Sharitz (1991) found that the water available to the plant, besides the light intensity and temperature, altogether can have a direct effect on the phenotypic characters of M. keisak, especially the shoot length. This corresponds with our data, as the three chosen habitats have different soil types, water contents and chemical constituents (Taia and El-Ghanem, 2002). Even so, the changes in the morphological characters in the studied species were insignificant. The observable changes were only in the color of the 
plant, its status, degree of branching and fruiting stage. These characters can be due to the water available to the plants, which differ according to the habitats and the soil salt contents. Mahmoud et al. (1985) pointed to the effect of environmental conditions, especially soil salinity, on the structure of the vegetation and degree of speciation. Meanwhile, they neglected the effects of environmental changes on morphology. Our results show that the main factor affecting the plant is water availability and this may be due to the studied species allocated under the same climatic factors. Alawi and Abulfatih (1996) have found that the taxonomic characters in Calotropis procera grown in two altitutidinal ranges were uniform and this is what we found in the results obtained. Our data reveal that the change in habitats which completely differ in their soil structure and constituents (Taia and El-Ghanem, 2002) has little effect on the phenotypic characters of the plants. The cross correspondence analysis between habitats revealed that the habitats have insignificant effect on the morphological characters and accordingly we can rely on these in taxonomic works.

\section{References}

Alawi, H.M. and H.A. Abulfatih. 1996. Uniformity of morphological characteristics of Calotropis procera found in two altitudinal ranges in Saudi Arabia. Arab Gulf Journal of Scientific Research 14:169-176.

Davis, P.H. and V.H. Heywood. 1973. Principles of Angiosperm Taxonomy. Robert E. Krieger Publishing Co., Huntington, New York.

Dunn, C.P. and R.R. Sharitz. 1991. Population and phenotypic plasticity in Murdannia kiesak (Commelinaceae). American Journal of Botany 78:1712-1723.

El-Demerdash, M.A., A.K. Hegazy and A.M. Zilay 1995. Vegetation-soil relationships in Tihamah coastal plains of Jazan region, Saudi Arabia. Journal of Arid Environments 30:161-174.

Grime, J.P. 1994. The role of plasticity in exploiting environmental heterogeneity. In Exploitation of Environmental Heterogeneity. M.M. Cadwell and
R.W. Pearcy (Editors), pp2-19, Academic Press, New York.

Mahmoud, A. A.M. El-Sheikh and F. Isawi. 1985. Ecology of the littoral salt marsh vegetation at Rabigh on the red sea coast of Saudi Arabia. Journal of Arid Environments 5:35- 42.

Mazer, S.J. and L.M. Wolfe. 1992. Density influences the expression of genetic variation in seed mass in wild radish (Raphanus sativus: Brassicaceae). American Journal of Botany 79:1185-1193.

Mazer, S.J. and D.L. Gorchov. 1996. Paternal effects on progeny phenotype: Distinguishing genetic and environmental causes. Evolution 50: 44-53.

Nicotra, A.B., R.L. Chazdon and C.D. Schlochting. 1997. Patterns of genotypic variation and phenotypic plasticity of light response in two tropical piper (Piperaceae) species. American Journal of Botany 84:1542-1553.

Pianka, E.R. 1988. Evolutionary Ecology, $4^{\text {th }}$. Ed. Harper and Row, New York.

Radford, A.E. 1986. Fundamentales of Plant Systematics. Harper and Row, New York.

Schlichting, C.D. 1986. The evolution of phenotypic plasticity in plants. Annual Review of Ecology and Systematics 17: 667-693.

Schlichting, C.D. and D.A. Levin. 1984. Phenotypic plasticity of annual Phlox: test of some hypotheses. American Journal of Botany 71:252-260.

Sultan, S.E. 1987. Evolutionary implications of phenotypic plasticity in plants. Evolution Biology 21:127-178.

Sultan, S.E. 1995. Phenotypic plasticity and plant adaptation. Acta Botanica Neerlandica 44:363383.

Taia, W.K. and W.M. El-Ghanem. 2001. City vegetation analysis of three habitats at El-Riyadh. Bulletin of Pure and Applied Sciences 20B:53-63.

Taia, W.K. and W.M. El-Ghanem. 2002. Comparative ecological studies on the natural vegetation of three different transects within El-Riyadh Region. Ph.D. thesis, Girl’s College of Education, El-Riyadh, Saudi Arabia..

Received: October 2003

Approved September 2005 